\title{
Maamme viimeaikaisesta väestönkehityksestä
}

\author{
Valtiot. tri PAAVO PIEPPONEN \\ Väestöpoliittinen Tutkimuslaitos
}

Väestöntutkimuksen vuosikirjan lukijoille on tarkoitus antaa jatkuvasti katsauksia alan ajankohtaisista ilmiöistä. Tällaiseksi on tarkoitettu myöskin tämä katsaus maamme viimeaikaiseen väestönkehitykseen. Vuosikirjan VI niteessä, joka ilmestyi 1960 , on luotu katsaus demografiseen kehitykseen pohjoismaissa (Forsberg) ja katsaus maapallon väestöpulmaan YK:n laskelmien valossa (Strömmer). Tämänkertaisessa katsauksessa on tarkoitus pysyä kotimaan väestöoloissa.

Jotta katsaus saisi enemmän ajallista perspektiiviä, on lähdetty vuodesta 1950 ja seurattu väestönkehitystä nykyaikaan niin pitkälle kuin viralliset tilastot tätä kirjoitettaessa sallivat. Useimmissa tapauksissa tutkimuskausi käsittää siten 14 vuotta. Tässä ajassa jo tulevat näkyviin muutoksetkin, mikäli sellaisia on tapahtunut.

\section{Väestön tila}

Väkiluku ja urbaaninen väestö

Jo 1950-luvulle siirryttäessä oli väkiluku sivuuttanut 4 miljoonan rajan. Samalla vuosikymmenellä ei vielä päästy yli 4.5 miljoonaa. Se tapahtui vasta vuonna 1962, jonka päättyessä väkiluku oli 4523200 asukasta. Ennustettu väkiluku vuoteen 1990 ilmenee oheisesta kuviosta.

Väestön jakaantuminen toisaalta kaupunkien ja kauppalain ja toisaalta maaseudun kesken on meillä vielä se, että enemmistö asuu maalaiskunnissa. Tarkas- telukauden alussa asui kaupungeissa ja kauppaloissa vain $32.3 \%$. Vuoden 1963 päättyessä tämä prosenttiluku on noussut lähes 10 prosenttiyksiköllä eli 42:een. Absoluuttisin luvuin ilmaistuna kaupunkija kauppalaväestön kasvu tarkastelukaudella on ollut yli 600000 , mikä on lähes sama kuin koko maan väkiluvun kasvu.

Urbaanisen väestön nopeaan kasvuun ovat luonnollisen väestönlisäyksen ohella vaikuttaneet toisaalta hallinnolliset muutokset eräiden maalaiskuntien muuttuessa kauppaloiksi ja toisaalta maalaiskunnista kaupunkeihin ja kauppaloihin suuntautuva muuttoliike. Vertailuajankohtana on viiden väkirikkaan maalaiskunnan, Karhulan, Kuusankosken, Järvenpään, Kemijärven ja Espoon muuttuminen kauppalaksi lisännyt kaupunki- ja kauppalaväestön osuutta nopeammin kuin muutoin olisi tapahtunut. Lapuan muuttuminen kauppalaksi vuoden 1964 alussa on arvion mukaan nostanut urbaanisen väestön osuuden $42,4 \%$ :iin.

\section{Sukupuolirakenne}

Sukupuolirakenteen puolesta väestö on naisvaltaista. Vuonna 1950 oli 1000 miestä kohti 1092 naista. Tässä suhteessa on kyllä tapahtunut jonkinverran tasaantumista sillä vuonna 1962 oli vastaava luku 1073. Eri ikäluokissa ovat suhteet kuitenkin erilaiset. Niinpä alle 20-vuotiaassa väestössä on miespuolisia enemmän kuin naispuolisia. 20-30-vuotiaiden kohdalla sukupuolijakautuma on tasoissa. Tämän jälkeen naiset alkavat olla enemmistönä ja mitä vanhempiin ikäryhmiin 
T a u l u 1. Väkiluku 1950-1963

Table 1. Population 1950-1963

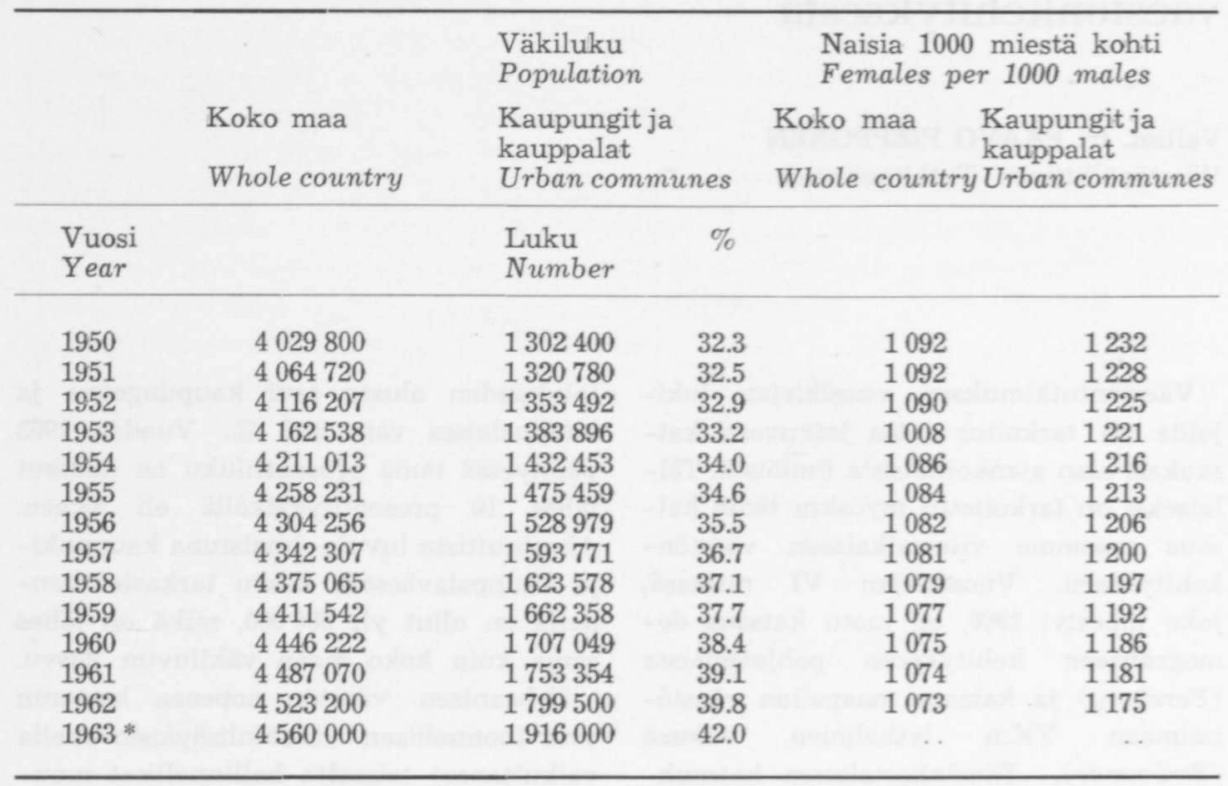

tullaan, sitä suuremmaksi naisvaltaisuus kasvaa. Taulusta 1 havaitsemme, että naisvoittoisuus on erityisen suuri kaupungeissa ja kauppaloissa.

\section{Ikärakenne}

Ikärakenteessa on oleellista vanhojen ikäluokkien eli 65 vuotta täyttäneiden sekä absoluuttinen että suhteellinen lisääntyminen. Vanhusten osuus väestöstä vuonna 1950 oli $6.7 \%$, mutta vuoden 1962 päättyessä se oli kohonnut $7.5 \%$ :iin. Muiden suurten ikäryhmien, jotka on esitetty taulussa 2, vaihtelut 50-luvulla ovat jossain määrin epäselviä. Ehkä yleisin piirre on, että tarkastelukauden alussa työikäisen väestön osuus väheni, mutta loppupuolella se on jälleen alkanut nousta. Samanaikaisesti on alle 15-vuotiaiden osuus alkanut vähentyä tarkastelukauden lopulla, niin että vuoden 1961 päättyessä vajaat $30 \%$ on ollut tämänikäisiä. Vuodesta 1950 lähtien suurimman ikäluokan muodostavat ssuuret ikäluokat, eli 194650 syntyneet (vrt. tässä niteessä olevaa Sweetserin ja Piepposen tutkielmaa).
Taulu 2. Väestön ikäjakautuma 19501962

Table 2. Age structure, 1950-1962

\begin{tabular}{lllll}
\hline $\begin{array}{l}\text { Vuosi } \\
\text { Year }\end{array}$ & $0-14$ & $15-64$ & $65-$ & \\
\hline & & & & \\
1950 & 30.0 & 63.3 & 6.7 & 100.0 \\
1951 & 30.3 & 63.0 & 6.7 & 100.0 \\
1952 & 30.5 & 62.8 & 6.7 & 100.0 \\
1953 & 30.5 & 62.7 & 6.8 & 100.0 \\
1954 & 30.6 & 62.6 & 6.8 & 100.0 \\
1955 & 30.8 & 62.3 & 6.9 & 100.0 \\
1956 & 30.5 & 62.5 & 7.0 & 100.0 \\
1957 & 30.8 & 62.2 & 7.0 & 100.0 \\
1958 & 30.6 & 62.3 & 7.1 & 100.0 \\
1959 & 30.5 & 62.3 & 7.2 & 100.0 \\
1960 & 30.0 & 62.7 & 7.3 & 100.0 \\
1961 & 29.5 & 63.0 & 7.5 & 100.0 \\
1962 & 28.7 & 63.8 & 7.5 & 100.0 \\
\hline
\end{tabular}

\section{Väestönmuutokset}

Avioituvuus

Väkiluvun kasvuun tai vähenemiseen vaikuttaa kolme väestönmuutostekijää: syntyvyys, kuolevuus ja muuttoliike. Kun syntyvyys kytkeytyy hyvin likeisesti 


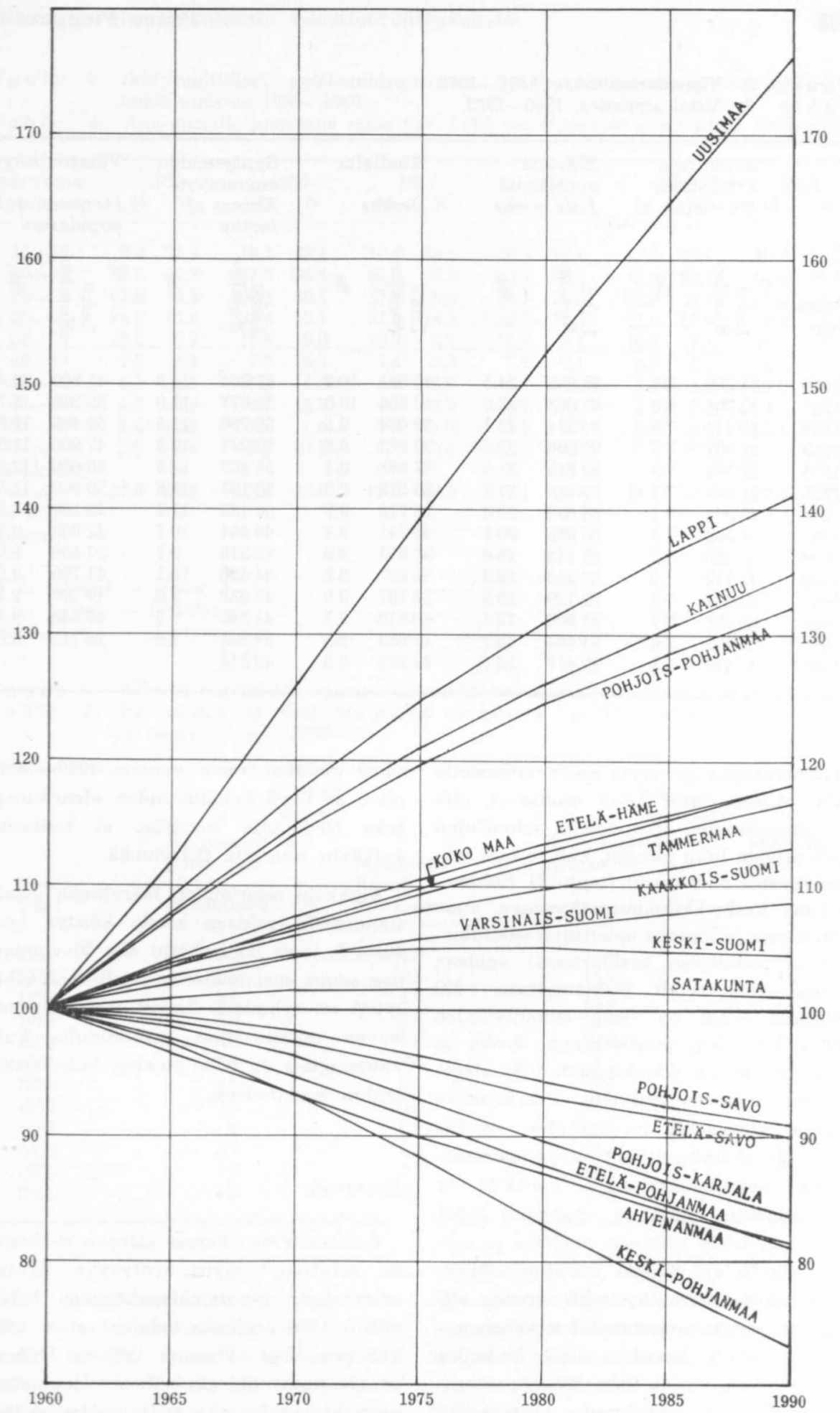

Ennustettu väkiluku vuosina $1965,1970,1975,1980,1985$ ja 1990 koko maassa ja eri talousalueilla. Vuoden 1960 väkiluku kullakin alueella $=100$.

(Lähde: Tilastokatsauksia N:o 10, 1963) 
T a u l u 3. Väestönmuutokset 1950-1963

Table 3. Vital statistics, 1950-1963

\begin{tabular}{|c|c|c|c|c|c|c|c|c|c|c|}
\hline \multirow[b]{2}{*}{$\begin{array}{l}\text { Vuosi } \\
\text { Year }\end{array}$} & \multicolumn{2}{|c|}{$\begin{array}{l}\text { Solmittuja } \\
\text { avioliittoja } \\
\text { Marriages }\end{array}$} & \multicolumn{2}{|c|}{$\begin{array}{l}\text { Elävänä } \\
\text { syntyneitä } \\
\text { Live births }\end{array}$} & \multicolumn{2}{|c|}{$\begin{array}{l}\text { Kuolleita } \\
\text { Deaths }\end{array}$} & \multicolumn{2}{|c|}{$\begin{array}{l}\text { Syntyneiden } \\
\text { enemmyys } \\
\text { Excess of } \\
\text { births }\end{array}$} & \multicolumn{2}{|c|}{$\begin{array}{l}\text { Väestönlisäys } \\
\begin{array}{l}\text { Increase of } \\
\text { population }\end{array}\end{array}$} \\
\hline & 孛芯 & ஓి & 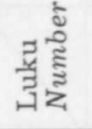 & $a^{8}$ & 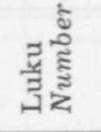 & ஓ & 丞芯 & 8 & 引 & $a^{8}$ \\
\hline 1950 & 34205 & 8.5 & 98065 & 24.5 & 40681 & 10.2 & 57384 & 14.3 & 41800 & 10.4 \\
\hline 1951 & 32206 & 8.0 & 93063 & 23.0 & 40386 & 10.0 & 52677 & 13.0 & 35200 & 8.7 \\
\hline 1952 & 32414 & 7.9 & 94314 & 23.1 & 39024 & 9.5 & 55290 & 13.5 & 52400 & 12.8 \\
\hline 1953 & 31807 & 7.7 & 90866 & 22.0 & 39925 & 9.6 & 50941 & 12.3 & 47900 & 11.6 \\
\hline 1954 & 32599 & 7.8 & 89845 & 21.5 & 37988 & 9.1 & 51857 & 12.4 & 50600 & 12.1 \\
\hline 1955 & 32640 & 7.7 & 89740 & 21.2 & 39573 & 9.3 & 50167 & 11.8 & 50000 & 11.8 \\
\hline 1956 & 33004 & 7.7 & 88896 & 20.8 & 38713 & 9.0 & 50183 & 11.7 & 49100 & 11.5 \\
\hline 1957 & 31333 & 7.2 & 86985 & 20.1 & 40741 & 9.4 & 46244 & 10.7 & 42000 & 9.7 \\
\hline 1958 & 31360 & 7.2 & 81148 & 18.6 & 38833 & 8.9 & 42315 & 9.7 & 37400 & 8.6 \\
\hline 1959 & 31712 & 7.2 & 83253 & 18.9 & 38827 & 8.8 & 44426 & 10.1 & 41700 & 9.5 \\
\hline 1960 & 32834 & 7.4 & 82129 & 18.5 & 39797 & 9.0 & 42332 & 9.6 & 40500 & 9.1 \\
\hline 1961 & 34222 & 7.7 & 81996 & 18.4 & 40616 & 9.1 & 41380 & 9.3 & 40848 & 9.1 \\
\hline 1962 & 34251 & 7.6 & 81454 & 18.1 & 42889 & 9.5 & 38565 & 8.6 & 36172 & 8.0 \\
\hline $1963 *$ & 33539 & 7.4 & 82417 & 18.1 & 42203 & 9.3 & 40214 & & & \\
\hline
\end{tabular}

avioituvuuteen on syytä ensin tarkastella tätä. Absoluuttiset luvut osoittavat, että tarkastelukauden alkupuolella solmittujen avioliittojen luku pieneni, kun se taas viime vuosina on noussut (taulu 3). Suhteutettuna keskiväkilukuun (kyseisen vuoden alussa ja lopussa todettujen väkilukujen aritmeettiseen keskiarvoon) voidaan todeta sama trendi. Suhteutettuna 1000 asukasta kohti on tämä avioituvuuden mitta kuitenkin puutteellinen, koska se ei ota huomioon ikärakennetta eikä aikaisempia avioitumissuhteita. Tarkemman kuvan saamiseksi on laskettu vuosille 1955-60 ikäryhmittäiset avioituneisuusluvut avioitumiskelpoista henkilöä ts. naimattomia, leskiä ja eronneita kohti. Tämä on tehty erikseen miehille ja naisille (taulu 4). Kaikki ikäryhmät käsittävä lukusarja osoittaa sekä miesten että naisten parissa avioituvuuden vähenemisen 50-luvun lopulla, mikä kuitenkin kääntyy nousuun v. 1960. Tästä poikkeavat kuitenkin nuorimman ikäryhmän, 15-19-vuotiaiden luvut. Sekä miesten että naisten parissa ne kohoavat jatku- vasti pudoten vasta vuonna 1960. Näin ollen se lievä avioituvuuden aleneminen, joka 50-luvulla todettiin, ei koskenut kaikkein nuorinta ikäryhmää.

Kaikkein nuorimman ikäryhmän avioituvuudesta voidaan saada käsitys taulusta 5 , jossa on laskettu alle 20 -vuotiaiden osuus ensimmäiseen avioliittoon vihityistä eri ryhmissä. Luvut osoittavat jatkuvaa nousua niin maaseudulla kuin kaupungissa ja niin poikien kuin tyttöjenkin keskuudessa.

\section{Syntyvyys}

Avioituvuuden kanssa samaan suuntaan on kehittynyt myös syntyvyys. Syntyneisyysluku (syntymätapahtumien lukumäärä 1000 asukasta kohden) oli v. 1950 24.5 promillea. Vuosina 1982 ja 1963 se on alentunut 18.1 promilleen. Huomattakoon kuitenkin, että syntyvyyden mittaluvut eivät kauden lopulla noudata samaa trendiä kuin avioituvuuden mittaluvut. 
$\mathrm{T}$ a u $1 \mathrm{u}$ 4. Ikäryhmittäiset avioituneisuusluvut 1000 avioitumiskelpoista henkilöä kohti vuosina $1955-1960$

$\mathrm{T} a \mathrm{ble}$ 4. Age-specific marriage rates per 1000 marriageable population, 1955-1960

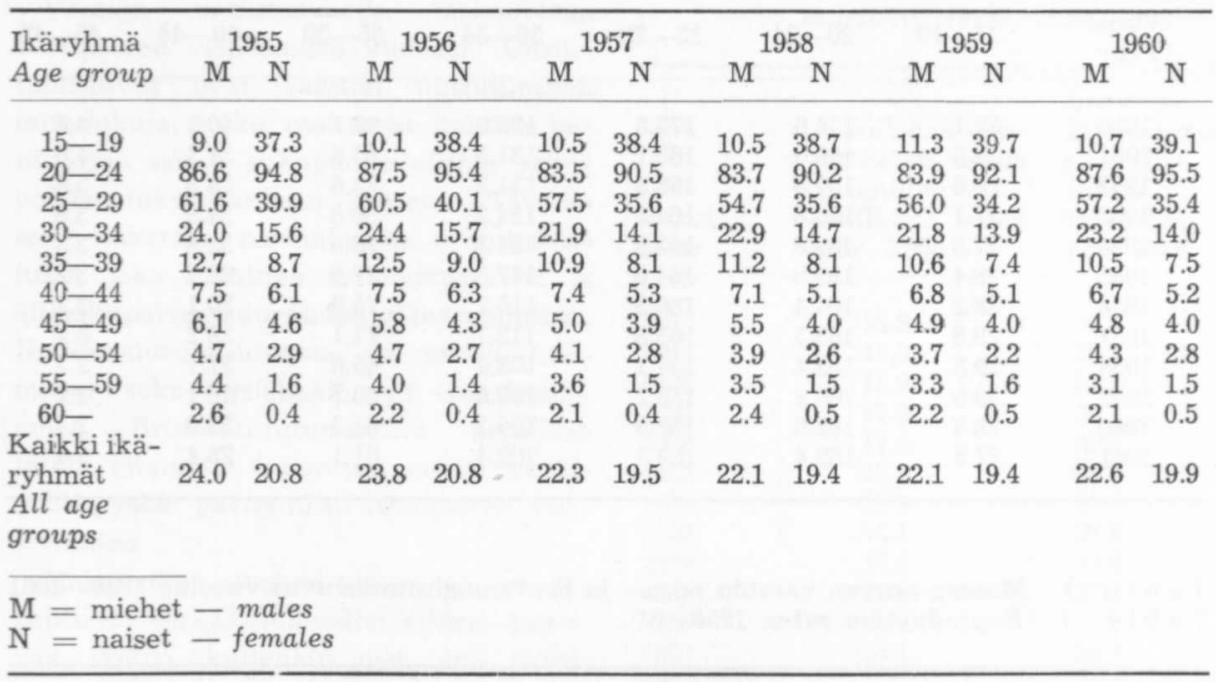

Taulu 5. Alle 20-vuotiaiden osuus ensimmäiseen avioliittoon vihityistä 1950-1961 Table 5. Percentage of first marriages contracted by males and females under 20 years of age, $1950-1961$

\begin{tabular}{|c|c|c|c|c|}
\hline \multirow[b]{2}{*}{$\begin{array}{l}\text { Vuosi } \\
\text { Year }\end{array}$} & \multicolumn{2}{|c|}{$\begin{array}{l}\text { Miehet } \\
\text { Males }\end{array}$} & \multicolumn{2}{|c|}{$\begin{array}{l}\text { Naiset } \\
\text { Females }\end{array}$} \\
\hline & $\begin{array}{l}\text { Kaupungit ja } \\
\text { kauppalat } \\
\text { Urban } \\
\text { communes }\end{array}$ & $\begin{array}{l}\text { Maaseutu } \\
\text { Rural } \\
\text { communes }\end{array}$ & $\begin{array}{l}\text { Kaupungit ja } \\
\text { kauppalat } \\
\text { Urban } \\
\text { communes }\end{array}$ & $\begin{array}{l}\text { Maaseutu } \\
\text { Rural } \\
\text { communes }\end{array}$ \\
\hline 1950 & 5.5 & 4.8 & 13.6 & 18.9 \\
\hline 1951 & 5.6 & 4.5 & 14.7 & 18.9 \\
\hline 1952 & 5.7 & 4.3 & 15.3 & 19.8 \\
\hline 1953 & 6.0 & 4.6 & 16.6 & 21.5 \\
\hline 1954 & 6.0 & 4.6 & 16.8 & 22.3 \\
\hline 1955 & 6.1 & 4.6 & 17.4 & 22.5 \\
\hline 1956 & 7.1 & 5.1 & 18.8 & 23.1 \\
\hline 1957 & 7.8 & 5.8 & 19.5 & 25.3 \\
\hline 1958 & 7.6 & 5.9 & 19.9 & 24.9 \\
\hline 1959 & 8.4 & 5.8 & 20.0 & 25.5 \\
\hline 1960 & 7.9 & 5.8 & 20.5 & 24.8 \\
\hline 1961 & 7.9 & 6.2 & 21.4 & 25.1 \\
\hline
\end{tabular}

Eri ikäryhmien hedelmällisyysluvut (elävänä syntyneiden lasten määrä 1000 naista kohden kussakin ikäluokassa) osoittavat erilaista kehitystendenssiä tarkastelukauden aikana (taulu 6). Ikäryhmissä $15-19$ ja 20-24 vuotta erikoishedelmällisyysluvut ovat tarkastelukau- den alkuvuosina olleet pienemmät kuin loppuvuosina. Tosin nuorimmassa ikäryhmässä hedelmällisyysluvut ovat parina viimeisenä vuotena jälleen alentuneet. Sitä vastoin vanhemmissa ikäryhmissä kehitys on ollut päinvastainen: erikoishedelmällisyysluvut ovat näissä ikäryh- 
T a u lu 6. Ikäryhmittäiset hedelmällisyysluvut vuosina 1950-1961

Table 6. Age-specific fertility rates, 1950-1961

\begin{tabular}{llllllll}
\hline $\begin{array}{l}\text { Vuosi } \\
\text { Year }\end{array}$ & $15-19$ & $20-24$ & $25-29$ & $30-34$ & $35-39$ & $40-44$ & $45-49$ \\
\hline & & & & & & & \\
1950 & 27.1 & 154.6 & 175.5 & 136.0 & 93.1 & 40.4 & 4.6 \\
1951 & 24.8 & 150.0 & 168.1 & 131.5 & 85.6 & 37.3 & 4.0 \\
1952 & 26.6 & 159.8 & 168.3 & 131.2 & 83.6 & 36.8 & 5.6 \\
1953 & 27.1 & 155.8 & 164.2 & 124.2 & 80.8 & 34.9 & 3.6 \\
1954 & 27.8 & 159.6 & 162.6 & 121.3 & 76.9 & 32.8 & 3.3 \\
1955 & 28.4 & 159.9 & 164.6 & 117.3 & 77.2 & 33.2 & 3.2 \\
1956 & 28.2 & 164.4 & 166.5 & 116.2 & 75.0 & 30.1 & 3.1 \\
1957 & 29.8 & 163.5 & 163.5 & 112.1 & 71.1 & 29.2 & 3.2 \\
1958 & 29.3 & 153.4 & 154.1 & 103.4 & 65.6 & 27.1 & 2.7 \\
1959 & 29.5 & 160.2 & 158.2 & 106.6 & 65.7 & 26.1 & 2.7 \\
1960 & 28.3 & 162.6 & 158.9 & 104.1 & 61.3 & 25.0 & 2.4 \\
1961 & 27.8 & 159.4 & 159.3 & 102.4 & 61.1 & 25.4 & 2.4 \\
\hline
\end{tabular}

T a ulu 7. Maassa asuvan väestön netto- ja bruttouusiutumisluvut vuosina 1950-1961 Table 7. Reproduction rates, $1950-61$

\begin{tabular}{|c|c|c|c|c|c|c|}
\hline \multirow[b]{2}{*}{$\begin{array}{l}\text { Vuosi } \\
\text { Year }\end{array}$} & \multicolumn{3}{|c|}{$\begin{array}{l}\text { Nettouusiutumisluvut } \\
\text { Net reproduction rates }\end{array}$} & \multicolumn{3}{|c|}{$\begin{array}{l}\text { Bruttouusiutumisluvut } \\
\text { Gross reproduction rates }\end{array}$} \\
\hline & $\begin{array}{l}\text { Koko maa } \\
\text { Whole } \\
\text { country }\end{array}$ & $\begin{array}{l}\text { Kaupungit } \\
\text { Urban } \\
\text { communes }\end{array}$ & $\begin{array}{l}\text { Maaseutu } \\
\text { Rural } \\
\text { communes }\end{array}$ & $\begin{array}{l}\text { Koko maa } \\
\text { Whole } \\
\text { country }\end{array}$ & $\begin{array}{l}\text { Kaupungit } \\
\text { Urban } \\
\text { communes }\end{array}$ & $\begin{array}{l}\text { Maaseutu } \\
\text { Rural } \\
\text { communes }\end{array}$ \\
\hline $1950^{1}$ & 1.379 & 1.063 & 1.525 & 1.536 & 1.161 & 1.707 \\
\hline 1951 & 1.385 & 1.193 & 1.495 & 1.466 & 1.248 & 1.592 \\
\hline 1952 & 1.409 & 1.127 & 1.592 & 1.491 & 1.179 & 1.695 \\
\hline 1953 & 1.362 & 1.130 & 1.517 & 1.441 & 1.181 & 1.615 \\
\hline 1954 & 1.361 & 1.140 & 1.512 & 1.439 & 1.192 & 1.608 \\
\hline 1955 & 1.352 & 1.154 & 1.493 & 1.430 & 1.207 & 1.588 \\
\hline 1956 & 1.345 & 1.162 & 1.478 & 1.423 & 1.215 & 1.572 \\
\hline 1957 & 1.318 & 1.139 & 1.453 & 1.393 & 1.190 & 1.545 \\
\hline 1958 & 1.239 & 1.079 & 1.363 & 1.310 & 1.127 & 1.449 \\
\hline 1959 & 1.267 & 1.079 & 1.411 & 1.339 & 1.128 & 1.500 \\
\hline 1960 & 1.254 & 1.093 & 1.382 & 1.325 & 1.142 & 1.468 \\
\hline 1961 & 1.245 & 1.105 & 1.361 & 1.316 & 1.155 & 1.446 \\
\hline \multicolumn{7}{|c|}{$\begin{array}{l}1 \text { Vuonna } 1950 \text { kauppalat on laskettu maseutuun kuuluviksi - In 1950, market } \\
\text { towns were included in rural communes. }\end{array}$} \\
\hline
\end{tabular}

missä jatkuvasti pienentyneet. Lievän poikkeuksen tässä tekee kuitenkin ikäryhmä 25-29 vuotta. Eräs tarkastelukaudella tapahtunut muutos on vielä huomioimatta. Alkuvuosina on 20-29-vuotiaiden hedelmällisyysluku ollut suurin. Tämän ryhmän hedelmällisyysluvun aleneminen sekä toisaalta 20-24-vuotiaiden erikoishedelmällisyysluvun nousu on johtanut siihen, että vuonna 1957 näiden ikäryhmien hedelmällisyysluvut olivat yhtä suuret. Senjälkeen ovat jo nuoremman ikäryhmän hedelmällisyysluvut olleet jopa suuremmat. Kun samanaikaisesti myös 15-19-vuotiaiden erikoishedelmällisyysluvut ovat housseet, on tämä kehitys merkinnyt sitä, että nuoremmat ikäluokat ovat tulleet entistä hedelmällisemmiksi ja lasten synnyttäminen on siirtynyt nuoremmille naisille. Tämä on osalta yhtey- 
dessä siihen seikkaan, että avioliittojen solmimisikä on alentunut ja ensisynnyttäjät ovat siten nuorempia.

Väestön uusiutumisella tarkoitetaan sukupolven vaihtumista uudeksi. Uusiutumisluvut ovat väestön uusiutumisen mittalukuja, jotka osoittavat kahden perättäisen samaa sukupuolta olevan sukupolven lukumääräisen suhteen. Tavallisesti lasketaan naislinjainen uusiutumisluku, joka ilmoittaa tytärsukupolven ja äitisukupolven suuruuden välisen suhteen. Nettouusiutumisluvussa on otettu huomioon sekä hedelmällisyys että kuolevuus. Bruttouusiutumisluku sensijaan jättää ottamatta huomioon ennen hedelmällisyysiän päättymistä tapahtuvan kuolevuuden.

Molemmissa uusiutumisluvuissa on tapahtunut tarkastelukauden aikana jatkuvaa laskua kuitenkin niin, että nettouusiutumisluku oli alimmillaan vuonna 1958 (taulu 7). Molemmat suhdeluvut ovat maaseudulla korkeammat kuin kaupungeissa. Erityisesti kiinnittyy huomio kaupunkien nettouusiutumislukuihin vuosina 1958 ja 1959, jolloin ne olivat vain vähän yli yhden. Myös bruttouusiutumisluvut olivat samoina vuosina kaupungeissa alhaiset. Mainittujen vuosien jälkeen ovatkin molemmat luvut kaupungeissa kohonneet, mutta edelleenkin maaseudun luvut ovat korkeammat kuin kaupunkien ja kauppaloiden.

\section{Kuolevuus}

Kuolevuutta voidaan tarkastella monen mittaluvun avulla. Yleinen kuolleisuusluku ilmoittaa kuinka monta henkilöä 1000 asukasta kohden jonakin aikana on kuollut. Taulusta 3 voimme todeta tämän luvun vähentyneen vuodesta 1950 , jolloin se oli 10.2, vuoteen 1962 mennessä 9.5:een. Kuolleisuusluku on ollut 50-luvulla alempanakin, esim. vuonna 1959 se oli 8.8 . Niin imeväiskuolleisuus (ensimmäisellä ikävuodella kuolleiden suhde elävänä syntyneiden lasten määrään) kuin myös kuolleena syntyneiden osuus osoittavat näiden alentuneen tarkastelukauden ajan
Taulu 8. Kuolleena syntyneiden osuus ja imeväiskuolleisuus 19501963

Table 8. Stillbirth rates and infant mortality rates, 1950-1963

\begin{tabular}{lcl}
\hline & $\begin{array}{l}\text { Kuolleena syn- } \\
\text { tyneiden osuus } \\
\text { promillea }\end{array}$ & $\begin{array}{l}\text { Imeväis- } \\
\text { kuolleisuus } \\
\text { promillea } \\
\text { Infant } \\
\text { mortality } \\
\text { per 1 1000 }\end{array}$ \\
$\begin{array}{lcl}\text { Vuosi } \\
\text { Year }\end{array}$ & $\begin{array}{l}\text { peo } \\
\text { pertes }\end{array}$ \\
\hline 1950 & 18.5 & 43.5 \\
1951 & 18.0 & 35.4 \\
1952 & 18.9 & 31.8 \\
1953 & 17.6 & 34.2 \\
1954 & 17.6 & 30.6 \\
1955 & 17.9 & 29.7 \\
1956 & 18.3 & 25.7 \\
1957 & 17.1 & 27.9 \\
1958 & 16.9 & 24.5 \\
1959 & 15.9 & 23.6 \\
1960 & 15.1 & 21.0 \\
1961 & 14.1 & 20.8 \\
1962 & $\cdots$ & 20.5 \\
$1963 *$ & $\cdots$ & 18.0 \\
\hline
\end{tabular}

(taulu 8). Erityisen voimakasta on imeväiskuolleisuuden aleneminen 43.5 promillesta 18.0 promilleen. Tämä onkin nykyään eräs kaikkein alhaisimmista imeväiskuolleisuusluvuista mitä maailmassa on. Kummankin ilmiön alenemiseen ovat epäilemättä vaikuttaneet parantuneet terveydelliset, sosiaaliset ja lääkinnälliset olot.

Tilastollisen päätoimiston äskettäin julkisuuteen saattamat kuolleisuus- ja eloonjäämistaulut vuosilta 1956-1960 osoittavat samanlaista tendenssiä. Eriikäisten miesten ja naisten kuolemanvaarat 50 -luvun loppupuolella ovat vähentyneet. Erityisesti vuotta nuorempien poikien ja tyttöjen kohdalla on väheneminen ollut huomattavaa, $24 \%$ edellisen viisivuotiskauden vastaavista luvuista (taulu 9). Myös jäljelläolevan eliniän pitenemistä on tapahtunut jokaisessa ikäluokassa. Vastasyntyneiden keskimääräinen jäljelläoleva elinaika on viime vuosikymmenen lopulla ollut miehillä 64.90 ja naisilla 71.57 vuotta. Erotus on 6.67 vuotta, joka on suurimpia mitä maailmassa on todettu (taulu 10). 
Taulu 9. Eri ikäisten miesten ja naisten kuolemanvaarat vuosina 1951-1955 ja 1956-1960

Table 9. Male and female mortality rates at different ages in the years 1951-1955 and 1956-1960

\begin{tabular}{|c|c|c|c|c|c|c|}
\hline $\begin{array}{l}\text { Ikä } \\
\text { Age }\end{array}$ & $\begin{array}{l}\text { Miehet } \\
1951-55\end{array}$ & $\begin{array}{l}\text { - Males } \\
1956-60\end{array}$ & $\%^{1}$ & $\begin{array}{c}\text { Naiset - } \\
1951-55\end{array}$ & $\begin{array}{l}\text { Females } \\
\quad 1956-60\end{array}$ & $\%$ \\
\hline 0 & 35.71 & 27.29 & 76 & 28.25 & 21.47 & 76 \\
\hline 1 & 3.61 & 3.00 & 83 & 2.84 & 2.67 & 94 \\
\hline 2 & 2.17 & 1.60 & 74 & 1.40 & 1.41 & 101 \\
\hline 3 & 1.58 & 1.09 & 69 & 1.10 & 0.86 & 78 \\
\hline 4 & 1.18 & 1.04 & 88 & 0.82 & 0.67 & 82 \\
\hline 5 & 1.07 & 0.79 & 74 & 0.75 & 0.54 & 72 \\
\hline 10 & 0.60 & 0.58 & 97 & 0.39 & 0.35 & 90 \\
\hline 29 & 1.70 & 1.32 & 78 & 1.05 & 0.72 & 69 \\
\hline 35 & 3.29 & 2.95 & 90 & 1.97 & 1.64 & 83 \\
\hline 50 & 11.44 & 11.19 & 98 & 5.37 & 4.87 & 91 \\
\hline 75 & 91.68 & 89.05 & 97 & 72.04 & 69.55 & 97 \\
\hline
\end{tabular}

Ta u l u 10. Eri ikäisten miesten ja naisten keskimääräiset jäljellä olevat elinajat vuosina 1951 -1955 ja $1956-1960$.

T a ble 10. Male and female expectation of life at different ages in the years $1951-1955,1956-1960$.

\begin{tabular}{|c|c|c|c|c|}
\hline $\begin{array}{l}\text { Ikä } \\
\text { Age }\end{array}$ & $\begin{array}{l}\text { Miehet - } \\
\text { 1951-55 }\end{array}$ & $\begin{array}{c}\text { - Males } \\
1956-60\end{array}$ & $\begin{array}{l}\text { Naiset - } \\
\quad 1951-55\end{array}$ & $\begin{array}{l}\text { Females } \\
1956-60\end{array}$ \\
\hline 0 & 63.37 & 64.90 & 69.84 & 71.57 \\
\hline 1 & 64.71 & 65.72 & 70.86 & 72.14 \\
\hline 2 & 63.94 & 64.92 & 70.06 & 71.33 \\
\hline 3 & 63.08 & 64.02 & 69.16 & 70.43 \\
\hline 4 & 62.17 & 63.09 & 68.24 & 69.49 \\
\hline 5 & 61.25 & 62.15 & 67.29 & 68.54 \\
\hline 10 & 56.51 & 57.37 & 62.47 & 63.68 \\
\hline 20 & 47.01 & 47.81 & 52.82 & 53.94 \\
\hline 35 & 33.53 & 34.13 & 38.78 & 39.62 \\
\hline 50 & 20.96 & 21.41 & 25.20 & 25.92 \\
\hline 75 & 6.55 & 6.79 & 7.31 & 7.57 \\
\hline
\end{tabular}

\section{Muuttoliike}

Alussa on jo mainittu muuttoliikkeen vilkkaus urbaanista väestöä lisäävänä tekijänä. Tarkastelukauden alussa maassamuuton muuttaneisuusluku oli huomattavan korkea, $43.3 \%$, mutta jo seuraavana vuonna se putosi tarkastelukauden alimpaan eli $34.2 \%$ :een. Vuonna 1960
Ta ulu 11. Maassamuutto 1950-1962

Table 11. Internal migration, 19501962

\begin{tabular}{lcc}
\hline $\begin{array}{l}\text { Vuosi } \\
\text { Year }\end{array}$ & $\begin{array}{l}\text { Kuntaan muuttaneita } \\
\text { To commune }\end{array}$ & $\begin{array}{l}\text { \%or } \\
\text { per } 1000\end{array}$ \\
\hline & & \\
1950 & 173163 & 43.3 \\
1951 & 138350 & 34.2 \\
1952 & 158583 & 38.8 \\
1953 & 160019 & 38.6 \\
1954 & 164257 & 39.3 \\
1955 & 180764 & 42.6 \\
1956 & 179934 & 41.9 \\
1957 & 177204 & 40.9 \\
1958 & 163909 & 37.5 \\
1959 & 176783 & 40.0 \\
1960 & 221177 & 49.9 \\
1961 & 214919 & 48.1 \\
1962 & 214041 & 47.5 \\
& & \\
\hline
\end{tabular}

saavutti muuttaneisuusluku tarkastelukauden korkeimman arvon, $49.9 \%$ (taulu 11). Näin on vuosittain yli 200000 henkilöä eli lähes $5 \%$ väestöstä siirtynyt asuinkunnasta toiseen.

Maastamuuttoa koskevat tilastot, sen jälkeen kun vuonna 1954 poistettiin pohjoismaista passipakko työnhakijoilta, ovat olleet näiltä osin puutteelliset. Tätä ku- 
vastaa se, että kun siirtolaisten lukumäärä vielä vuonna 1951 oli 19644 , niin se v. 1954 oli vain 2976. Siirtolaistilastomme ilmeisesti antaakin melko luotettavan kuvan muihin kuin pohjoismaihin suuntautuvasta siirtolaisuudesta. Tältä osin voidaan todeta lukujen alentuneen vuosien 1957-58 tasosta, jolloin siirtolaisia oli yli 5000 . Viimeisin, vuodelta 1962 oleva luku 724 on tarkastelukauden pienin. Tarkkoja tietoja pohjoismaihin suuntautuvasta siirtolaisuudesta ei ole. Norjassa on suoma- laisia 1000-2000 henkeä, Tanskassa n. 1000 ja Ruotsissa 100000 . Ruotsin virallisen tilaston osoittama työssä olevien suomalaisten lukumäärä on viime vuosina kasvanut. Sen perusteella on tehty arvio, että viime vuosina Suomesta olisi vuosittain muuttanut Ruotsiin 60008000 henkilöä. Verrattuna syntyneiden määrään tämä tarkoittaa sitä, että joka 10:ttä syntynyttä lasta vastaa yksi Ruotsiin siirtynyt suomalainen. 